\title{
PARENTAL LEAVE POLICIES IN EUROPE AND NORTH AMERICA
}

Christopher J. Ruhm

Jackqueline L. Teague

Working Paper No. 5065

\section{NATIONAL BUREAU OF ECONOMIC RESEARCH 1050 Massachusetts Avenue \\ Cambridge, MA 02138 \\ March 1995}

We would like to thank Rebecca Blank and Ronald Ehrenberg for helpful comments on an earlier version of this manuscript. This paper is part of NBER's research program in Labor Studies. Any opinions expressed are those of the authors and not those of the National Bureau of Economic Research.

() 1995 by Christopher J. Ruhm and Jackqueline L. Teague. All rights reserved. Short sections of text, not to exceed two paragraphs, may be quoted without explicit permission provided that

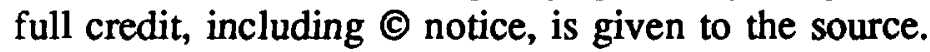




\title{
PARENTAL LEAVE POLICIES IN EUROPE AND NORTH AMERICA
}

\begin{abstract}
Despite widespread international implementation, limited information is currently available on the economic impact of mandated family leave policies. This paper increases our understanding of the nature and effects of parental leave entitlements in several ways. First, we provide a brief history of family leave legislation in Europe and North America and summarize arguments relating to the efficiency and incidence of mandated leave. Second, we have constructed a longitudinal data set detailing durations of job-protected leave in 17 countries, during the $1960-89$ period, and use this information to examine recent trends in the regulations. The data indicate that family leave durations grew rapidly during the decade of the 1970 s, with more modest increases since that time. Third, we provide an exploratory investigation of the relationship between mandated leave policies and macroeconomic outcomes. The econometric estimates provide little support for the view that moderate periods of parental leave reduce economic efficiency but rather hint at a modest beneficial impact, particularly when considering paid time off work.
\end{abstract}

Christopher J. Ruhm Department of Economics University of North Carolina Greensboro Greensboro, NC 27412-5001 and NBER
Jackqueline L. Teague

Center for Economics Research

Research Triangle Institute

Research Triangle Park, NC 27709-2194 


\section{Parental Leave Policies in Europe and North America}

\section{Introduction}

Attitudes towards women's roles at home and in the workplace have changed dramatically during the twentieth century. More women are presently employed than ever before and many no longer stop working at childbirth. Reflecting this trend, virtually all industrialized countries now provide entitlements to job-protected absences from employment during the period surrounding childbirth. ${ }^{1}$ Frequently fathers, as well as mothers, qualify for time off work and most countries provide income support during the leave period.

Until recently, the United States was a notable exception. Prior to 1993, there was no federal legislation requiring U.S. employers to provide parental leave and only a few states had mandated job protection. This changed with the passage of the Family and Medical Leave Act (FMLA) of 1993, which requires medium and large companies to supply 12 weeks of unpaid parental leave. Although the legislation is modest by international standards, since the leave is for a comparatively short duration and is unpaid, it represents an important change in U.S. policy and occurs at a time when many Europeans are questioning the wisdom of pervasive employment mandates. ${ }^{2}$ Furthermore, advocates have argued for broadening the U.S. legislation. For instance, the Carnegie Task Force on Meeting the Needs of Younger Children (1994) has recommended extending the law to cover smaller companies and favors providing at least some income assistance during the absence from work.

Despite the widespread international implementation of parental leave entitlements, limited information is currently available on their economic impact. One reason for the scarcity is that countries have typically passed or changed policies independently, making it difficult to

1. Kamerman (1988, 1991a) summarizes international parental leave entitlements.

2 One respect in which the U.S. law is relatively broad is that it extends job-protection to persons caring for sick children and relatives. 
ascertain trends. The absence of consistent longitudinal data has further constrained the ability of researchers to examine whether family leave has positive or negative economic effects. ${ }^{3}$

This paper improves our understanding of family leave in three ways. First, we briefly describe the international development of parental leave policies and summarize arguments concerning the efficiency and incidence of this type of labor market intervention. Second, we have compiled a cross-country data set providing a fairly consistent time-series of parental leave regulations. Using this data, we report trends in leave entitlements for the 30 year period 1960-89. Third, we supply a preliminary econometric analysis of the macroeconomic consequences of paid and unpaid leave.

\section{Parental Leave Policies in Europe and the United States}

Legislated maternity leave has a long history in Europe. Germany adopted the first such law in 1883, followed by Sweden in 1891, and France in 1928. A 1919 meeting of the International Labor Organization led to an initial multinational recommendation regarding pregnant working women and advocated three fundamentals of maternity protection: a leave period, cash benefits, and job-protection (Stoiber, 1989).

Early legislation was typically paternalistic in its concern for the health of the child and mother. Prenatal and postnatal leave were compulsory and supplementary income support or job-protection seldom provided. After World War II, the pronatalist rationale became quite explicit in social policies across Europe. Moeller (1993) notes that every country participating in the Second World War grappled with the status of females. Most nations had recruited women into occupations previously held exclusively by men and, following the hostilities, many wished

3 By contrast, other types of employment mandates have been the subject of considerable research. For example, a proliferation of analysis followed passage of the 1988 Worker Retraining and Notification Act, which required some U.S. employers to provide advance notice of plant closings and mass layoffs (e.g. Ehrenberg \& Jakubson, 1988; Lazear, 1990; Swaim \& Podgursky, 1990; Addison \& Portugal, 1992; Ruhm, 1992, 1994). 
to return women to the home. The issues of family allowances, protective legislation, female participation in the wage labor force, and family-law reform predominated in West Germany as well as other European countries. Often the motivation for the policies was to restore women to their "proper" roles as mother and wife (Frank and Lipner, 1988). Many nations (e.g., Denmark, Finland, Greece, Japan, the Netherlands, and France) mandated compulsory pregnancy leave but failed to prohibit dismissal from jobs.

The late 1960s initiated two decades of change. During this period, the concept of maternity leave evolved from a prohibition on employing women during the period surrounding pregnancy to one of time off work to care for newborns and young children, combined with job security for the parents. Countries with compulsory leave added prohibitions against dismissal from employment. Portugal, Spain, Finland and Canada instituted job-protected leave during the 1969-71 period. France and the Netherlands passed similar legislation in 1975 and 1976. Denmark, Ireland and Greece ratified such laws between 1980 and 1984 . Other nations, including Switzerland, Ireland and the United Kingdom also inaugurated regulations which provided for job-protected maternity leave during this period.

Despite these changes, vestiges of the previous protective legislation continue in many countries. For example, postnatal absences from employment remain compulsory rather than voluntary in Austria, Spain, Switzerland, Finland, France, Norway, and Sweden (Brocas, 1990). Austria, France, and Italy also require prenatal leave. In some countries (e.g. France), the motivations for parental leave legislation continue to be pronatalist and paternalistic in nature.

Income support is provided during the leave period in almost all industrialized countries, with wage replacement rates generally exceeding $50 \%$ and often surpassing $80 \%$. The income maintenance is usually supplied through social insurance, although some nations (e.g. Belgium, Germany, Italy, and the United Kingdom) require the employer to contribute part of the benefit. 
Several countries (e.g. Canada, Denmark, Finland, France, Germany, Greece, Italy, Norway, Portugal, Sweden) have made the leave available to either parent but far more mothers than fathers actually take time off work. ${ }^{4}$

In addition to the policies of individual countries, the EC Social Charter has recently established a minimum standard of 14 weeks of maternity leave, to be paid at a level no less than the individual would have received if absent from work because of sickness (Addison \& Siebert, 1993). This represents a slight dilution of the original proposal which would have required leave at full pay. On the other hand, the eligibility criteria for paid leave (12 months of service) is less than the previous requirements in some countries.

By contrast, the United States did not mandate parental leave until passage of the Family and Medical Leave Act in 1993. The FMLA diverges from European policies in a variety of ways. Most importantly, the leave is unpaid, which differentiates it from all EC countries who provide income support during at least some of the absence from work. ${ }^{5}$ Also notable, the 12 weeks prescribed in the law is much shorter than the period of entitlement throughout most of Europe. $^{6}$

Some working mothers in the U.S. did have rights to job-protected parental leave, prior to passage of the FMLA. After enactment of the Pregnancy Discrimination Act in 1980, states providing temporary disability insurance (California, Hawaii, New Jersey, New York, and Rhode Island) were required to cover childbirth and pregnancy as well. In most of these states, the leave period was 26 weeks and a cash benefit equaling approximately half the wage of the average employee was paid (Bookman, 1991). As late as 1988, only two of the five states had

4 For example, Haas (1991) delineates large and enduring differences in the percentage of Swedish mothers and fathers making use of parental leave.

5 U.S. companies are responsible for continuing health insurance during the leave period.

6 U.S. leave need not be taken all at once, however, and the employee can work on a reduced schedule if it is certified as medically necessary. 
legislated job-protection at the time of maternity (Kamerman, 1991b). Several other states did require unpaid leaves including: Tennessee (4 months); California, Montana, and Rhode Island (13 weeks); Oregon (12 weeks); lowa, Maine, and Massachusetts ( 8 weeks); Wisconsin and Minnesota (6 weeks). By 1992, 25 states had enacted some form of job-protected parental leave (Trzcinski \& Alpert, 1994).

Not withstanding these activities, relatively few U.S. women were entitled to job-protected maternity leave prior to the of federal legislation. Trzcinski (1991) reports that only $13.9 \%$ of large Connecticut firms (more than 500 employees) offered explicit infant care leave in 1988 , although some workers received protection through other sickness and disability policies. Meisenheimer's (1989) analysis of the 1988 Bureau of Labor Statistics Employee Benefits Survey indicates that $36 \%$ of full-time employees in medium and large firms (100 workers or more) were covered by some type of leave policies, with just $2 \%$ receiving paid leave. ${ }^{7}$ Since small firms supply nonwage benefits less frequently than larger ones, these figures overstate the overall entitlement to family leave in the U.S..

\section{Efficiency and Incidence of Mandated Family Leave}

Economists are generally wary of mandated benefits, such as parental leave, arguing that they interfere with the free operation of labor markets and so are likely to reduce welfare. Most simply, it is assumed that workers and firms will voluntarily agree to the provision of family leave if the expected benefits exceed the associated costs. Conversely, if costs surpass the benefits, workers will forgo the leave in exchange for receiving higher compensation. By eliminating this flexibility, an employer mandate may make one or both parties worse off. Parental leave benefits could also increase occupational segregation, by raising the relative cost of employing women in some types of jobs, and lead to higher unemployment for the

7 Most of these benefits were provided through general leave-of-absence policies, rather than through specific parental leave plans. 
groups most likely to use it. ${ }^{8}$

Proponents of parental leave, by contrast, typically assert that time off work is necessary to protect the welfare of infants and emphasize the importance of placing women on an equal footing with men (Kamerman, 1991a; Bravo, 1991; Stoiber, 1990; Gilliand, 1989; Decker, 1991). Unintended consequences of mandated leave are generally ignored or assumed to have relatively minor costs.

The economic arguments which have been made favoring leave entitlements usually focus on retaining human capital or reducing unemployment. For instance, Trzcinski (1991) claims that the mandated benefit would improve the position of women by increasing job tenure, decreasing the unemployment occurring when caregivers reenter the labor market, breaking down entry barriers preventing women from entering highly paid occupations, and raising wages in female-dominated jobs. Spalter-Roth \& Hartmann (1990) calculate that the average benefits of parental leave are six times greater than the costs, mainly because of reduced unemployment and the preservation of job tenure. Dalto (1989) postulates that family leave raises productivity by allowing workers to continue in positions in which their sector-specific skills are best utilized. These contentions, however, generally do not identify sources of market failure which will be rectified by mandating entitlements to parental leave. For example, if Spalter-Roth \& Hartmann are correct that the benefits of family leave far exceed the costs, without market failure, we would expect to observe widespread voluntary arrangements allowing for job-protected absences from work.

In economic terms, entitlements to family leave could be desirable if the time off work provides a positive externality. For instance, young children might receive better care when at least one parent is away from employment and, as a result, be healthier and incur fewer

8 See Summers (1989) or Mitchell (1990) for detailed discussions of mandated benefits. 
medical costs. To the extent these expenses are not fully paid for by the family (e.g. with universal health care), workers will undervalue the leave benefit and a mandate has the potential to improve efficiency. Although the presence of externalities is implicit in most arguments used to support entitlements to parental leave, we know of no efforts to quantify their existence or importance.

Adverse selection under asymmetric information provides a second potential economic justification for mandated leave. It is reasonable to assume that workers have greater knowledge regarding the probability of having children (and so taking time off work) than their employers. As discussed by Summers (1989) and Krueger (1994), among others, individuals with high probabilities of using the leave will disproportionately choose to work for companies providing it, resulting in increased costs for these firms. With competitive labor markets, the employers will need to compensate by decreasing wages, leading persons with low probabilities of taking time off work to shun these firms, in order to avoid the loss of earnings. ${ }^{9}$ If the entitlement to parental leave were instead required by the government, the adverse selection problem would be avoided and all workers would receive coverage. ${ }^{10}$

9 Consider the following example. "Type $A$ " individuals constitute half the labor force and have an $80 \%$ probability of using parental leave. "Type $B$ " persons account for the remaining $50 \%$ of the work force and have a $20 \%$ probability of taking time off work. The cost to the employer of providing leave to any given worker is 1 and the benefit to employees using it is 2 . The economy-wide expected benefits are therefore $1([(.5)(.8)(2)+(.5)(.2)(2)]$ and the associated costs are $.5([(.5)(.8)(1)+(.5)(.2)(1)]$. A firm which reduced wages by .5 , in exchange for providing leave, would only attract type $A$ individuals, since the expected benefit to the B's (.4) is less than the wage reduction. The expected cost of providing leave to type $A$ persons is .8 , implying that the company would also lose money on these individuals. The employer could only avoid a loss by reducing wages by at least .8 (but less than 1.6). Thus, voluntarily provided leave would never be received by type $B$ individuals.

10 Blank \& Freeman (1993) make similar arguments in support of a variety of social insurance programs. They also point out that if there are work requirements for receiving the benefit, economic efficiency may be raised by encouraging employment. The inefficiency of privately negotiated labor market contracts, under asymmetric information, has also been demonstrated in a variety of other contexts. For instance, McGuire \& Ruhm (1993) indicate that excessive drug testing will occur, while Kuhn (1992) and Levine (1991), respectively, show that advance notice of job terminations and just-cause employment security regulations may be 
Aghion \& Hermalin (1990) have shown that, without a mandate, there are even situations where socially desirable parental leave will not be provided to any workers. They point out that individuals with low probabilities of taking time off work will signal this to employers by accepting contracts with no (or very limited) provisions for leave. In some circumstances a pooling equilibrium occurs, whereby workers with high probabilities of using parental leave will do better by mimicking their counterparts (by accepting jobs with companies not offering the benefit) than by revealing information on their propensity to take time off work. As a result, too little parental leave will be provided and a mandate is potentially pareto-improving.

\section{Data}

Our analysis uses a newly constructed data set covering 17 industrialized nations over the 1960-1989 time period. The countries included are: Austria, Belgium, Canada, Denmark, Finland, France, Germany, Greece, Ireland, Italy, the Netherlands, Norway, Portugal, Spain, Sweden, Switzerland, and the United Kingdom. ${ }^{11}$ Information on parental leave was obtained from the International Labour Office's Legislative Series, their 1984 global survey on "Protection of Working Mothers", and from Social Security Programs Throughout the World, which has been published at approximately two year intervals since 1958.

Assembling the data posed a variety of problems. First it is difficult to compile comparable information on leave entitlements across countries. Our measures of parental leave refer to job-protected absences from work to care for infants or young children. Job-protection means that dismissal is prohibited during pregnancy and reinstatement is guaranteed at the end of the leave period. ${ }^{12}$ As mentioned, many European countries enacted

\footnotetext{
underprovided.

11 Japan and the United States are excluded because no leave was mandated during the sample period in the United States and the duration of leave was constant in Japan (at 12 weeks) from 1960 through the last quarter of 1987 (when it was increased to 14 weeks).
} 
compulsory "maternity protection" during the 1940 s or 1950 s but did not prohibit dismissals until much later. Job-protection provisions were added throughout much of Europe during the period covered by the data.

Second, there are ambiguities concerning how to treat partially paid absences from work and family allowances which are not tied to employment. In this data, paid leave refers to supplements which are directly related to the worker's previous earnings, as distinguished from social insurance payments available to individuals independent of their employment histories. Although we primarily focus on differentiating between unpaid and paid leave, information was also obtained on average wage replacement rates and we constructed a measure of "full pay equivalent weeks", calculated as the average replacement rate multiplied by the number of weeks of paid leave. ${ }^{13}$ We do not distinguish between time off work which is available only to the mother and that which can be taken by either parent.

Third, countries differ in their qualification requirements for receiving parental leave. Since there was no obvious way to account for these disparities, the leave durations refer to workers who meet all qualifying conditions. This overstates the pervasiveness of compulsory leave but does not necessarily bias the analysis of time trends, since the conditions for receiving leave have not been modified in most countries during the sample period. ${ }^{14}$ Changes which have occurred have generally been in the direction of making the leave easier to qualify for (by reducing the number of hours or weeks of work needed), thus our data probably

12 We define mandated leave durations as the minimum time the government requires employers to allow their employees to be off work. These will diverge from the actual absences if individuals choose to return sooner or if longer leave periods are voluntarily agreed upon. 13 Some countries offer flat rate payments, rather than basing the benefit on a percentage of earnings. Full pay equivalent weeks were not calculated in these cases.

14 There are large cross-country differences in the proportion of women on maternity leave at any point in time. For instance, $1.8 \%$ and $1.4 \%$ of Danish and French working women were away from the job for this reason in 1988 , as compared to just $0.3 \%$ and $0.5 \%$ of their counterparts from Portugal and Greece (Commission of the European Communities, 1990). It is not clear whether differences in eligibility criteria play any role in explaining these disparities. 
understate the increase in family leave entitlements occurring over time.

The dependent variables in the econometric analysis include per capita gross domestic products (GDP), employment-to-population (EP) ratios, civilian labor force participation rates (LFPR), and unemployment rates (UNRATE). Per capita GDP is measured in 1980 dollars and exchange rates, using a consistent series obtained for the $1960-87$ period from OECD National Accounts. The labor market outcomes were compiled over the 1968-88 period, for women only and for males and females together, using information from the OECD publication Labour Force Statistics: 1968-1988. Corresponding labor force data for the years prior to 1968 contain many gaps and breaks in series and so were not analyzed. Information on the national populations (of civilians aged 15 to 64) were obtained from various issues of Labour Force Statistics and are used below to weight the data. ${ }^{15}$

\section{Trends in Parental Leave}

Widespread availability of job-protected parental leave is a relatively recent phenomenon. To illustrate this, figures 1 and 2 summarize time trends in leave entitlements for the 30 year period ending in 1989. Three types of absences are considered: total weeks of leave (LEAVE), weeks of paid leave (PAID), and full pay equivalent weeks (PDWKS), defined as the average wage replacement rate multiplied by the number of weeks of paid leave.

PDWKS is calculated for the 13 countries (excluding Germany, Norway, Switzerland, and the United Kingdom) providing workers on leave with a percentage of their previous pay (rather than a flat rate) throughout the observed period. The graphs differ in that figure 2 weights the observations by the size of the country's working age population, whereas the figure 1 treats all nations as having an equal weight.

Whereas durations of mandated leave remained at relatively low levels throughout most

15 Italy reports statistics for 14 to 64 year olds. Some countries (e.g. Austria, Greece, and Portugal) do not exclude the armed forces from these figures. 
of the 1960 s, the decade of the 1970 s was characterized by sharp increases in leave entitlements. For example, (weighted) leave allowances rose from their 1969 averages of 14.3, 9.2, and 4.4 weeks for LEAVE, PAID, and PDWKS, respectively, to 57.4, 23.3, and 15.3 weeks in 1980. Job-protected time off work expanded still further during the 1980 s, albeit at a slower rate -- weighted mean durations were $68.0,33.4$, and 17.3 weeks in 1989 . The weighted means (displayed in figure 2) are consistently higher than their unweighted counterparts (shown in figure 1) for total and paid leave, implying that large nations provided relatively generous benefits. Interestingly, the longer durations were not accompanied by higher wage replacement rates, with the result that there is no corresponding country size pattern in full pay equivalent weeks.

Table 1 summarizes the parental leave provisions in effect in 1989, the final year of our data. In that year, the 17 countries offered a minimum of 10 weeks of paid leave, with 11 nations mandating entitlements of between 12 and 18 weeks and 3 countries (Finland, Germany, and Sweden) requiring companies to permit more than a year off work. Over half the nations allowed additional absences without pay, although in only 4 cases (Austria, France, Norway, and Spain) was the unpaid leave substantial. A portion of the leave could be taken by the fathers In 10 of the 17 countries. While the conditions required to qualify for the leave varied, persons with more than a year of service were usually covered.

Table 2 details the total and paid leave available in each country at approximately 10 year intervals beginning in 1960. As mentioned, job-protected family leave was only sporadically offered before 1970 but increased rapidly during the following decade. Some countries raised durations several times during the 20 year period while others did so in a single increment. France and Spain are the most notable. France offered no job-protection until 1974 but provided 16 weeks of paid leave and an additional two years of unpaid absence by 1979 . 
Family leave was not required in Spain until 1970, at which point entitlement to leaves (largely unpaid) of up to 3 years was mandated. It is important to reemphasize that our definition of parental leave is restricted to time off work with dismissal prohibited during pregnancy and job reinstatement guaranteed. Both France and Spain provided payment to mothers prior to 1969, however, neither supplied employment-protection until the 1970 s.

Figure 3 displays plots of parental leave against per capita GDP for the years 1960 and 1987. The area of the circle denoting each observation is proportional to the country's working age population. For example, the highest entry on the top left plot indicates that Italy (a relatively large country) provided 40 weeks of total leave in 1960 . The smaller circle adjacent to it refers to Austria (with a much smaller population), which allowed absences of 38 weeks during that year.

The figure shows that per capita GDP was unrelated to durations of either total or paid leave in 1960 but that a positive correlation had developed by 1987 . It further suggests that large countries provided relatively lengthy absences from work, particularly during the early years of the data. The three most populus nations (Germany, Italy, and the United Kingdom) offered at least 12 weeks of paid leave in 1960, versus just 3 of the remaining 14 countries. The entitlements continued to be positively correlated with size in 1987, although the relationship was quite weak when considering paid time off work. ${ }^{16}$ Similar patterns are obtained for other years.

\section{Econometric Estimates}

Econometric techniques were next used to explore the relationship between parental

18 These findings are confirmed by regressions of leave durations on per capita GDP and the working age population. The coefficients are positive for both variables in 1960, with associated $t$ statistics of .01 for GDP and 1.51 for population size, when total leave is the dependent variable, and 1.01 and 2.16 , respectively, for paid leave. The coefficients are also positive in 1987, with t statistics of .29 and 1.65 (1.42 and .66) for total (paid) leave. 
leave, national incomes, and labor market outcomes. If the opponents of compulsory leave are correct, longer durations may be associated with lower employment and incomes, whereas the reverse is possible if family leave increases economic efficiency.

The basic regression equation is a two-way fixed-effect model of the form:

$$
Y_{i t}=\alpha_{i}+\beta_{1}+L_{i t} \gamma+\varepsilon_{i t},
$$

where $Y_{h}$ is the outcome for country $i$ at time $t, \alpha_{i}$ is a country-specific (time-invariant) intercept, $\beta_{1}$ is a time-specific (country-invariant) effect, $L$ indicates a vector of parental leave variables, and $\varepsilon$ is a disturbance term. The country fixed-effect controls for characteristics specific to a single nation (e.g. culture, resource endowments, and geography) which affect the dependent variables but do not change over time. The time-effect captures period-specific factors (e.g. oil shocks) which have a common impact across countries.

Dependent variables include the natural log of per capita GDP (in $\$ 1980$ ), the EP ratio, LFPR, and the unemployment rate. The three labor market outcomes are specified for men and women together and also for females separately. The unemployment rate combines the effects of changes in employment and labor force participation. For example, increased unemployment could result from a decline in job-holding, an increase in labor force participation, or some combination of the two.

The income equations are estimated by weighted least squares (WLS), with the square root of the working age population used to weight the data. Since the labor market variables are rates, restricted to the range zero through one, grouped data logit models are used for these outcomes. The dependent variable in logistic regression is the natural logarithm of the odds ratio; for instance, if $Y_{i t}$ is the participation rate, the regressand is $y_{i t}=\ln \left[Y_{i t}\left(1-Y_{i t}\right)^{-1}\right]$. The error term is heteroscedastic, with variance $\left[Y_{i t}\left(1-Y_{i t}\right) n_{i t}\right]^{-1}$, for $n_{i t}$ the working age population of country $i$ at time $t$. Efficiency is therefore maximized by using weighted least squares, with cell 
weights $\left[Y_{i t}\left(1-Y_{i t}\right) n_{i t}\right]^{1 / 2}$.

The econometric analysis is restricted to the $1968-1988$ period (1968-67 for GDP), rather than beginning with 1960 , for two reasons. First, relatively consistent data on the macroeconomic outcomes are available for these years. By contrast, information is missing and there are breaks in series for many of the labor market variables prior to 1968 . Second, restricting the investigation to a period of rapidly rising leave durations is likely to reduce the extent of spurious correlation between parental leave and unobservables which influence the outcomes of interest.

\subsection{Total Leave}

Results for various specifications of the basic model are summarized in table 3 . Year and country dummy variables are included, but not displayed in the tables, in these and all subsequent specifications. Total weeks of leave at year $t$ are controlled for in the top panel of table 3. The second panel also holds constant leave in year $\mathrm{t}-1$. The third panel shows estimates for a quadratic leave specification, to allow for nonlinearities the effect of the mandate. Reported p-values refer to the null hypothesis that the coefficients on LEAVE and LEAVE $^{2}$ are jointly equal to zero and the "maximum" effect occurs where the first derivative of the predicted leave impact is zero. ${ }^{17}$

The first panel of the table suggests that family leave is either unrelated or weakly positively correlated with per capita incomes but that the duration of leave is negatively associated with both employment-to-population ratios and labor force participation rates. The predicted decline in employment is larger than the change in participation, with the result that the unemployment rate increases.

In the second panel of table 3, the coefficient on LEAVE at $\mathrm{t}-1$ is larger than that at time

17 If $Y=\gamma_{1} L+\gamma_{2} L^{2}$, where $\gamma_{1}$ and $\gamma_{2}$ are coefficient estimates with opposite signs, the "maximum" occurs at $-\gamma_{1} / 2 \gamma_{2}$ weeks of leave. 
$t$, for all three labor market variables, indicating that much of the parental leave effect occurs with a delay. Nonetheless, little information is lost by deleting lags from the model. This is seen by noting that the coefficient on LEAVE at period $t$ in the top panel $(.000107,-.000603$, -.000453 , and .002594 for GDP, EP ratio, LFPR, and the unemployment rate) is virtually identical to the sum of the coefficients for years $t$ and $t-1$ in the second panel $(.000113$, $-.000689,-.000505$, and .002768 respectively). The subsequent analysis is therefore simplified by controlling for only contemporaneous leave durations.

The models are seriously misspecified when the leave effect is restricted to be linear. As shown in the lower panel of table 3 , the coefficient on LEAVE ${ }^{2}$ differs significantly from zero for all outcomes except the unemployment rate and approaches significance in that case. Furthermore, the interpretation of the effects of the mandate are dramatically altered by using the quadratic specification. Entitlement to lengthy leave continues to be negatively related to the labor market outcomes; however, short to moderate periods off work are strongly positively associated with both employment and incomes. The beneficial effects are predicted to grow through at least 7 months of leave entitlement for every macroeconomic outcome and, except for the unemployment rate, for the entire first year of parental leave.

\subsection{Causality Tests}

The above results suggest that short to moderate periods of family leave may increase economic efficiency, as measured by incomes and labor market status, while lengthy durations reduce it. It is possible, however, that causation actually runs in the reverse direction -- from economic outcomes to leave durations. For instance, there may be political pressure to raise the length of job-protected leave when the economy is depressed, in order to make it easier for new mothers to return to work. Alternatively, incomes and family leave durations could be positively correlated if the latter are normal goods, even if the mandates do not affect incomes. 
Although there is no way to definitively determine the direction of causation, useful information can be obtained by examining the relative timing of changes in leave durations and of the economic outcomes. Intuitively, if causation runs from parental leave to the macroeconomy, we expect that lagged values of the former will help to predict the latter. Conversely, if the direction of causation is reversed, lagged values of the macroeconomic variables will help to predict leave durations. ${ }^{18}$ More formally, we test for "Granger causality" (see Sims, 1972) using the model:

$$
\begin{aligned}
& Y_{i t}=\alpha_{11}+\beta_{1 t}+\gamma_{1} Y_{i t-1}+\delta_{1} L_{i t-1}+\varepsilon_{1 i t} \\
& L_{i t}=\alpha_{2 i}+\beta_{2 t}+\gamma_{2} Y_{i t-1}+\delta_{2} L_{i t-1}+\varepsilon_{2 i t \cdot} \cdot 1
\end{aligned}
$$

Family leave "Granger causes" (i.e. is causally prior to) macroeconomic outcomes if $\hat{\delta}_{1}$ differs statistically significantly from zero while $\hat{\gamma}_{2}$ does not.

Results of the Granger causality tests are summarized in table 4 . The top panel presents estimates for $\hat{\gamma}_{1}$ and $\hat{\delta}_{1}$, where the respective macroeconomic variable is the outcome and family leave the regressor of primary interest. The bottom panel shows corresponding estimates of $\hat{\gamma}_{2}$ and $\hat{\delta}_{2}$, with weeks of leave the dependent variable and a single (lagged) macroeconomic aggregate included as a covariate. All of the models also include country and year dummy variables.

Substantial support is provided for the hypothesis that causation runs from family leave to labor market status, rather than in the reverse direction. This is seen by noting that LEAVE at $\mathrm{t}-1$ has a statistically significant impact on the EP ratio, LFPR, and UNRATE at $t$ (see the top panel of table 4), whereas the data fail to uncover a statistically significant relationship (at the .05 level) between lagged values of per capita incomes or of the three labor force variables and

\footnotetext{
18 If both conditions are true, then causation is bi-directional or can not be ascertained.

19 The three labor market outcomes in equation $2 a$ ) are estimated as grouped data logit models. WLS is used for GDP and for all estimates of equation $2 \mathrm{~b}$ ).
} 
family leave durations. ${ }^{20}$ Coefficients on the lagged dependent variable are statistically significant in all eight equations, as would be expected, and there is little evidence that family leave either causes or is caused by national incomes.

\subsection{Paid vs. Unpaid Leave}

The impact of family leave could vary depending on whether or not payment is provided during the time-off work. For instance, the economic distortions might be larger for entitlements to paid than unpaid absences, since the former are more costly to employers. Conversely, efficiency enhancements might be restricted to paid leave, if parents can only afford to be away from the job if they receive compensation. To investigate these issues, we estimate the models with paid and unpaid leave controlled for separately.

Short to moderate durations of either type of leave are associated with relatively high EP ratios and labor force participation rates (see table 5). The employment effect is more pronounced for paid time off work, whereas a stronger impact on participation is observed for unpaid absences. As a result, paid (unpaid) leave of intermediate length is associated with decreased (increased) unemployment. The labor supply effects peak at around 9 months for unpaid time off work but increase through the longest observed entitlements to absences with pay. The first 15 months of paid leave are also correlated with higher per capita incomes but there is not a statistically significant relationship between unpaid leave and per capita GDP.

\subsection{Female Labor Force Status}

A mandated benefit which primarily affects an identifiable class of workers may (but need not) have a disproportionate impact on the employment of that group. ${ }^{21}$ Since family leave is primarily used by women (even in countries where men share the entitlement), it is

20 The lagged unemployment coefficient barely misses significance at the .05 level, however, and is significant at the 1 level.

21 See Gruber (1994) for a careful discussion of this issue. 
useful to examine whether stronger labor market effects are observed for women alone than for men and women together. Towards this end, table 6 displays econometric findings for female employment-to-population ratios, labor force participation rates, and unemployment rates. The top panel controls for total weeks of leave. Unpaid and paid absences are separately held constant in the lower panel.

The results are generally similar to those obtained for the entire labor force (see tables 3 and 5). In particular, moderate leave durations are associated with statistically significant increases in the EP ratios of women, with a stronger relationship observed for paid than unpaid time off work. Female labor force participation rates are also positively correlated with mandated leave, although the results are not as strong as for the full sample. Finally, unemployment rates are again positively (negatively) associated with unpaid (paid) leave of short to intermediate length.

\section{Simulations}

Logit coefficients are somewhat difficult to interpret, since the dependent variable is a log-odds ratio. To illustrate the effects of parental leave more clearly, table 7 therefore displays predicted values of the dependent variables at specified durations of paid and unpaid leave. For instance, the first two entries in the second column indicate that EP ratios would be expected to rise from $58.7 \%$ to $59.2 \%$ when a country moves from no mandated leave to entitling workers to 10 weeks of unpaid time off work. If the 10 weeks of leave were paid, the percentage of the population employed would be predicted to increase still further, to $59.5 \%$ (see row 6). ${ }^{22}$

The table highlights the generally stronger impact of paid than unpaid leave. For example, moving from 0 to 50 weeks of unpaid leave raises expected per capita (log) GDP,

22 Year and country variables are evaluated at their sample means in these calculations. 
employment-to-population ratios, and labor force participation rates by $-.06 \%, 1.79 \%$, and $1.98 \%$ respectively. The predicted increases from instituting an equivalent amount of paid leave are $.82 \%, 6.44 \%$, and $1.65 \%$. The most important disparity is the almost four times larger boost in employment for paid than unpaid the time off work.

There is little evidence that the labor market impact of parental leave is concentrated among women. The responsiveness of employment to paid leave and of the LFPR to either paid or unpaid time off work is greater for the full sample than for women only. For instance, switching from no leave to 50 weeks with pay is predicted to increase the EP ratio by $6.4 \%$ (from $58.7 \%$ to $62.5 \%$ ) and the participation rate by $1.7 \%$ (from $63.9 \%$ to $65.0 \%$ ), for the full sample, as compared to $2.6 \%(43.0 \%$ vs. $44.1 \%)$ and $-1.0 \%(47.3 \%$ vs. $46.9 \%)$ for women separately. Only when considering the relationship between unpaid leave and the employment-to-population ratio is the effect of a mandate larger for women alone than for the combined sample. In this case, increasing the entitlement from 0 to 50 weeks raises expected female employment rates by more than $4 \%$, versus a less than $2 \%$ rise in the overall EP ratio.

\section{Conclusion}

This paper increases our understanding of the nature and effects of parental leave policies in several ways. First, we provide a brief history of family leave entitlements in Europe and North America and summarize arguments pertaining to the efficiency of this type of mandate. Second, we have constructed a cross-country data set with information on parental leave in 17 countries over the $1960-89$ time period. We utilize these data to examine the evolution of leave regulations during a 30 year period of rapidly increasing entitlement. Third, we provide an exploratory investigation of the relationship between family leave, per capita incomes, and several labor market outcomes.

It is worth reemphasizing the conceptual ambiguities that frequently surround 
discussions of parental leave. Our data collection and analysis have focused upon job-protected absences from work. By contrast, the first countries to institute maternity leave typically did so to "protect" mothers or to increase birthrates. Employment security did not become a concern until much later. Thus, the economic and employment consequences of early leave policies could be quite different from those currently implemented.

Our research shows that job-protected parental leave grew rapidly in duration and frequency during the decade of the 1970s, with more modest increases since that time. Large countries are more likely to mandate entitlements to lengthy absences from work and the data provide some evidence that the parental leave is a normal good, increasing in duration as per capita incomes rise. The econometric investigation suggests that leave entitlements of moderate duration (especially when paid) operate to raise employment levels. Labor force participation rates are also higher in countries mandating short to intermediate durations of leave, although this increase is larger for unpaid than paid time off work. Worker rights to lengthy absences from jobs are associated with less favorable labor market outcomes.

These findings are preliminary and indicate the need for further investigation. For instance, it is important to understand why the employment effects of parental leave are not concentrated among women, even though they are the primary users of it. One possibility, suggested by Gruber's (1994) research on maternity benefits, is that changes in leave entitlements have a larger influence on the wages and work hours of women than men, without disproportionately affecting their probabilities of holding jobs.

The issue of causation is also problematic. Although the Granger causality tests suggest that changes in family leave precede corresponding movements in the macroeconomic variables, additional research using microdata would be helpful. Such study would need to be carefully undertaken, however, to minimize biases related to nonrandom selection into 
employment or the type of job held.

Keeping these caveats in mind, the econometric results do suggest beneficial effects of short to moderate durations of parental leave and particularly of paid absences from work surrounding the birth of a child. It is reassuring that findings provide no evidence that harmful effects are likely to result from the recent passage, in the United States, of the Family and Medical Leave Act. If anything, they suggest that the law may have a modest favorable effect on the macroeconomy. 


\section{References}

Addison, John T. and Pedro Portugal (1992) "Advance Notice and Unemployment: New Evidence from the 1988 Displaced Worker Survey" Industrial and Labor Relations Review, 45(4), 645-64.

Addison, John T. and W. Stanley Siebert (1993) Current Controversies. No. 6: Social Engineering in the European Community: The Socjal Charter. Maastricht and Beyond, London: The Institute of Economic Affairs.

Aghion, Phillipe and Benjamin Hermalin (1990) "Legal Restrictions on Private Contracts Can Enhance Efficiency" Journal of Law, Economics, and Organization, 6(2), 381-409

Blank, Rebecca and Richard Freeman (1993) "Evaluating the Connection Between Social Protection and Economic Flexibility", National Bureau of Economic Research Working Paper, No. 4338.

Bookman, Ann (1991) "Parenting Without Poverty: The Case for Funded Parental Leave," in Hyde and Essex, Parental Leave and Child Care (pp. 66-89). Philadelphia, PA: Temple University Press.

Brocas, Anne-Marie, Anne-Marie Cailloux and Virginie Oget (1990) Women and Social Security: Progress Towards Equality of Treatment, Geneva: International Labour Office.

Bravo, Ellen (1991) "Family Leave: The Need for a New Minimum Standard" in Hyde and Essex, Parental Leave and Child Care (pp. 165-175). Philadelphia, PA: Temple University Press.

Carnegie Task Force on Meeting the Needs of Young Children (1994) Starting Points: Meeting the Needs of Young Children. New York, N.Y.: Carnegie Corporation of New York.

Commission of the European Communities. Employment in Europe 1990. Belgium: Office for Official Publications of the European Communities.

Dalto, Guy C. (1989) "A Structural Approach to Women's Hometime and Experience-earnings Profiles: Maternity Leave and Public Policy," Population Research and Rolicy Review, 8(3), 247-266.

Decker, Linda (1991) "Keeping Mum," Pensions and Employee Benefits, 13(6), June, 17-19.

Ehrenberg, Ronald and George Jakubson (1988) Advance Notice Provisions in Plant Closing Legislation. Kalamazoo, MI: W.E. Upjohn Institute for Employment Research.

Frank, Meryl and Robyn Lipner (1988) "History of Maternity Leave in Europe and the United States," in Zigler and Frank The Parental Leave Crisis (pp. 3-22) New Haven: Yale University Press.

Gilliand, Pierre (1989) "Evolution of family policy in the light of demographic development in West European countries," International Social Security Review, 42(4), 395-426. 
Gruber, Jonathan (1994) "The Incidence of Mandated Maternity Benefits," American Economic Review, 84(3), 622-41.

Haas, Linda (1991) "Equal Parenthood and Social Policy: Lessons from a Study of Parental Leave in Sweden" in Hyde and Essex, Parental Leave and Child Care (pp. 375-405). Philadelphia,PA: Temple University Press.

International Labor Office Special Issue, "Protection of Working Mothers: An ILO Global Survey (1964-84)," Women at Work, 2, 1984.

Kaplan, Gisela (1992) Contemporary Western European Feminism, New York, NY: New York University Press.

Kamerman, Sheila B. (1991a) "Child Care Policies and Programs: An International Overview," Journal of Social Issues, $47(2), 179-196$.

Kamerman, Sheila B. (1991b) "Parental Leave and Infant Care: U.S. and International Trends and Issues, 1978-1988," in Hyde and Essex, Parental Leave and Child Care, (pp. 11-23). Philadelphia, PA: Temple University Press.

Kamerman, Sheila B. (1988) "Maternity and Parenting Benefits: An International Overview," in Zigler and Frank The Parental Leave Crisis (pp. 235-244) New Haven: Yale University Press.

Krueger, Alan B. (1994) "Observations on Employment-Based Government Mandates, With Particular Reference to Health Insurance," Working Paper \#323, Industrial Relations Section, Princeton University, January.

Kuhn, Peter (1992) "Mandatory Notice," Journal of Labor Economics, 10(2), 117-137.

Labour Force Statistics: 1957-1968, 1960-1971, 1962-82, 1966-1986. 1968-1988 (Paris: Organization for Economic Cooperation and Development, Department of Economics and Statistics, 1970, 1973, 1984, 1988, 1990).

Lazear, Edward P. (1990) "Job Security Provisions and Employment," Quarterly Journal of Economics, 55(3), August, 699-726.

Legislative Series, (Geneva: International Labour Office Publications, 1930, 1931, 1933, 1945-1948, 1950-1962, 1964-1973, 1975-1985, 1987).

Levine, David I. (1991) "Just-cause Employment Policies in the Presence of Worker Adverse Selection," Journal of Labor Economics, 9(3), 294-305.

Meisenheimer, Joseph R. (1989) "Employer Provisions for Parental Leave," Monthly Labor Review, October, 20-24.

McGuire, Thomas G. and Christopher J. Ruhm (1993) "Workplace Drug Abuse Policy," Journal of Health Economics 12(1), 19-38. 
Mitchell, Olivia (1990) "The Effect of Mandatory Benefit Packages" in Bassi, L., D. Crawford, and R. Ehrenberg (eds.) Research in Labor Economics, Vol. 11. Greenwich, CT: JAI Press, 297-320.

Moeller, Robert G. (1993) Protecting Motherhood: Women and the Family in the Politics of Postwar West Germany, Berkeley, CA: University of California Press.

National Accounts, Vol. I: Main Aggregates 1960-1987 (Paris: OECD Department of Economics and Statistics, 1989.)

Ruhm, Christopher J. (1992) "Advance Notice and Postdisplacement Joblessness" Journal of Labor Economics 10(1), 1-32.

Ruhm, Christopher J. (1994) "Advance Notice, Job Search, and Postdisplacement Earnings" Journal of Labor Economics 12(1), 1-28.

Sims, Christopher A. (1972) "Money, Income, and Causality" American Economic Review $62(4), 540-52$

Social Security Programs Throughout the World, (Washington D.C: Government Printing Office $1958,1961,1967,1969,1971,1973,1975,1977,1979,1983,1985$, and 1989)

Stoiber, Susanne A. (1990) "Family Leave Entitlements in Europe: Lessons for the United States," Compensation \&. Benefits Management, 6(2), Winter, 111-116.

Spalter-Roth, Roberta M. and Heidi I. Hartmann (1990) Unnecessary Losses: Costs to Americans of the Lack of Family and Medical Leave, Washington D.C.: Institute for Women's Policy Research, 1990.

Summers, Lawrence (1989) "Some Simple Economics of Mandated Benefits" American Economic Review, 79(2), 177-83.

Swaim, Paul and Michael Podgursky (1990) "Advance Notice and Job Search: The Value of An Early Start" Journal of Human Resources 25 (2), 147-78.

Trzcinski, Eileen and William T. Alpert (1994) "Pregnancy and Parental Leave in the United States and Canada" Journal of Human Resources 29 (2), 535-54.

Trzcinski, Eileen (1991) "Employers' Parental Leave Policies: Does the Labor Market Provide Parental Leave?" in Hyde and Essex Parental Leave and Child Care, (pp. 41-65) Philadelphia, PA: Temple University Press. 
Table 1: Parental Leave Provisions in 1989

\begin{tabular}{|c|c|c|c|c|}
\hline Country & $\begin{array}{l}\text { Total } \\
\text { Leave }\end{array}$ & $\begin{array}{l}\text { Paid Leave } \\
\text { ( } \% \text { of pay) }\end{array}$ & $\begin{array}{l}\text { Available } \\
\text { To Fathers }\end{array}$ & Qualification Conditions \\
\hline Austria & 67 wks & 16 wks $(100 \%)$ & None & $\begin{array}{l}10 \text { months of social insurance } \\
\text { coverage in last } 2 \text { years or } 6 \text { months } \\
\text { coverage in last year. }\end{array}$ \\
\hline Belgium & 14 wks & 14 wks $(71 \%)$ & None & 6 months coverage preceding leave. \\
\hline Canada & 24 wks & 15 wks $(60 \%)$ & 24 wks & $\begin{array}{l}15 \text { hours/week employment for } 20 \\
\text { weeks with same employer during last } \\
\text { year. }\end{array}$ \\
\hline Denmark & 28 wks & 28 wks $(90 \%)$ & 12 wks & $\begin{array}{l}6 \text { months coverage and employment } \\
\text { during previous year, including at } \\
\text { least } 40 \text { hours of work during } 4 \text { weeks } \\
\text { preceding leave. }\end{array}$ \\
\hline Finland & 69 wks & 69 wks $(80 \%)$ & 26 wks & $\begin{array}{l}3 \text { months employment, unless } \\
\text { involuntarily unemployed. }\end{array}$ \\
\hline France & 120 wks & 16 wks $(90 \%)$ & 104 wks & $\begin{array}{l}10 \text { months of insurance prior to leave } \\
\text { and at least } 200 \text { hours of work in } 3 \\
\text { months preceding the pregnancy. }\end{array}$ \\
\hline Germany & 83 wks & $\begin{array}{l}14 \text { wks ( } 100 \%) \\
69 \text { wks (flat rate) }\end{array}$ & 69 wks & $\begin{array}{l}12 \text { weeks of insurance or } 6 \text { months of } \\
\text { employment. }\end{array}$ \\
\hline Greece & 13 wks & 12 wks $(50 \%)$ & 12 wks & $\begin{array}{l}200 \text { days of employment during last } 2 \\
\text { years. }\end{array}$ \\
\hline Ireland & 18 wks & 14 wks $(70 \%)$ & None & 30 weeks of insurance contributions. \\
\hline Italy & 46 wks & 46 wks $(52 \%)$ & 26 wks & $\begin{array}{l}\text { Insured and employed at start of } \\
\text { pregnancy. }\end{array}$ \\
\hline Netherlands & 12 wks & 12 wks $(100 \%)$ & None & Insured and employed. \\
\hline Norway & 52 wks & 18 wks $(90 \%)$ & 40 wks & $\begin{array}{l}\text { Employed and insured at least } 6 \text { of } \\
\text { the last } 10 \text { months. }\end{array}$ \\
\hline Portugal & 12 wks & 12 wks $(100 \%)$ & 8 wks & Employed with 6 months of insurance. \\
\hline Spain & 156 wks & 14 wks $(75 \%)$ & None & $\begin{array}{l}\text { Insured } 9 \text { months, with } 6 \text { months of } \\
\text { contributions. }\end{array}$ \\
\hline Sweden & 78 wks & 72 wks $(90 \%)$ & 60 wks & Insured 8 months. \\
\hline Switzerland & 14 wks & 10 wks (flat rate) & None & $\begin{array}{l}\text { Up to } 9 \text { months insurance (depending } \\
\text { upon Canton). }\end{array}$ \\
\hline $\begin{array}{l}\text { United } \\
\text { Kingdom }\end{array}$ & 40 wks & 18 wks (flat rate) & None & $\begin{array}{l}6 \text { months of insurance contributions } \\
\text { during previous year and } 2 \text { years of } \\
\text { work with same employer. }\end{array}$ \\
\hline
\end{tabular}


Table 2: Parental Leave Durations In Selected Years

\begin{tabular}{|c|c|c|c|c|c|c|c|c|}
\hline \multirow{2}{*}{ Country } & \multicolumn{4}{|c|}{ Weeks of Leave } & \multicolumn{4}{|c|}{ Weeks of Paid Leave } \\
\hline & 1960 & 1969 & 1979 & 1989 & 1960 & 1969 & 1979 & 1989 \\
\hline Austria & 38 & 65 & 67 & 67 & 12 & 12 & 16 & 16 \\
\hline Belgium & 4 & 14 & 14 & 14 & 4 & 14 & 14 & 14 \\
\hline Canada & 0 & 0 & 17 & 24 & 0 & 0 & 15 & 15 \\
\hline Denmark & 0 & 0 & 0 & 28 & 0 & 0 & 0 & 28 \\
\hline Finland & 0 & 0 & 35 & 69 & 0 & 0 & 35 & 69 \\
\hline France & 0 & 0 & 120 & 120 & 0 & 0 & 16 & 16 \\
\hline Germany & 12 & 14 & 32 & 83 & 12 & 14 & 32 & 83 \\
\hline Greece & 0 & 0 & 0 & 13 & 0 & 0 & 0 & 12 \\
\hline Ireland & 0 & 0 & 0 & 18 & 0 & 0 & 0 & 14 \\
\hline Italy & 40 & 40 & 46 & 46 & 14 & 14 & 46 & 46 \\
\hline Netherlands & 0 & 0 & 12 & 12 & 0 & 0 & 12 & 12 \\
\hline Norway & 12 & 12 & 52 & 52 & 12 & 12 & 18 & 18 \\
\hline Portugal & 0 & 0 & 12 & 12 & 0 & 0 & 12 & 12 \\
\hline Spain & 0 & 0 & 156 & 156 & 0 & 0 & 14 & 14 \\
\hline Sweden & 12 & 36 & 78 & 78 & 12 & 36 & 54 & 72 \\
\hline Switzerland & 0 & 8 & 14 & 14 & 0 & 8 & 10 & 10 \\
\hline United Kingdom & 18 & 18 & 40 & 40 & 18 & 18 & 18 & 18 \\
\hline
\end{tabular}


Table 3: Fixed-Effect Estimates of the Relationship Between

Parental Leave and Macroeconomic Outcomes

\begin{tabular}{|c|c|c|c|c|}
\hline Regressor & $\begin{array}{l}\text { Log of Gross } \\
\text { Domestic } \\
\text { Product } \\
\text { (1) }\end{array}$ & $\begin{array}{c}\text { Employment- } \\
\text { to-Population } \\
\text { Ratio } \\
\text { (2) }\end{array}$ & $\begin{array}{c}\text { Labor Force } \\
\text { Participation } \\
\text { Rate } \\
\text { (3) }\end{array}$ & $\begin{array}{c}\text { Unemployment } \\
\text { Rate } \\
\text { (4) }\end{array}$ \\
\hline LEAVE at $t$ & $\begin{array}{c}.000107 \\
(1.05)\end{array}$ & $\begin{array}{c}-.000603 \\
(2.29)\end{array}$ & $\begin{array}{c}-.000453 \\
(2.13)\end{array}$ & $\begin{array}{c}.002594 \\
(3.08)\end{array}$ \\
\hline LEAVE at $t$ & $\begin{array}{l}.000170 \\
(1.05)\end{array}$ & $\begin{array}{c}7.19 \mathrm{E}-5 \\
(0.17)\end{array}$ & $\begin{array}{c}-.000106 \\
(0.31)\end{array}$ & $\begin{array}{l}.001255 \\
(0.87)\end{array}$ \\
\hline LEAVE at $t-1$ & $\begin{array}{c}-5.73 E-5 \\
(0.41)\end{array}$ & $\begin{array}{c}-.000761 \\
(2.05)\end{array}$ & $\begin{array}{c}-.000399 \\
(1.34)\end{array}$ & $\begin{array}{l}.001513 \\
(1.15)\end{array}$ \\
\hline LEAVE at $t$ & $\begin{array}{c}.001122 \\
(2.45)\end{array}$ & $\begin{array}{l}.004833 \\
(3.85)\end{array}$ & $\begin{array}{c}.003587 \\
(3.52)\end{array}$ & $\begin{array}{c}-.002889 \\
(0.72)\end{array}$ \\
\hline $\begin{array}{l}\text { LEAVE SQUARED } \\
\text { at } t\end{array}$ & $\begin{array}{c}-7.58 E-6 \\
(2.28)\end{array}$ & $\begin{array}{c}-4.07 E-5 \\
(4.42)\end{array}$ & $\begin{array}{c}-3.02 E-5 \\
(4.05)\end{array}$ & $\begin{array}{c}4.33 E-5 \\
(1.41)\end{array}$ \\
\hline P-Value & .0443 & .0000 & .0000 & .0035 \\
\hline $\begin{array}{l}\text { "Maximum" Leave } \\
\text { Effect }\end{array}$ & 74.0 wks & 59.4 wks & 59.4 wks & 33.4 wks \\
\hline Sample Size & 340 & 344 & 343 & 337 \\
\hline
\end{tabular}

Note: Sample includes 17 countries for 1968-88 time period (through 1987 for GDP). Country and year dummy variables are also included. LEAVE refers to the number of weeks of job protected maternity leave. Estimates in column (1) are obtained using weighted least squares (weighted by the square root of the working age population). Those in columns (2) through (4) are from grouped data logit models. Absolute values of $t$ statistics are shown in parentheses. The P-value refers to the total leave effect and is obtained by testing whether the coefficients on LEAVE and LEAVE SQUARED jointly differ from zero. 
Table 4: Granger Causality Tests

\section{Coefficient on Lagged Macroeconomic Variable}

$(\gamma)$
Coefficient on Lagged

Family Leave

(ठ)

Model: $Y_{i t}=\alpha_{1}+\beta_{t}+\gamma Y_{i t \cdot 1}+\delta L_{i t-1}+\varepsilon_{i t}$

\section{Dependent Variable $\left(Y_{i t}\right)$}

Log of Gross Domestic Product

$-3.95 \mathrm{E}-6$

Employment-to-Population Ratio

3.9923

(47.15)

4.2693

$(45.401)$

Unemployment Rate

8.3844

(16.49)
$-2.19 \mathrm{E}-4$

$-1.83 E-4$

2.18E-3

(4.01)

Model: $L_{k}=\alpha_{1}+\beta_{t}+\gamma Y_{k-1}+\delta L_{k-1}+\varepsilon_{k t}$

Explanatory Variable $\left(Y_{n-1}\right)$

Log of Gross Domestic Product

8.5170

(0.49)

.7464

(24.13)

Employment-to-Population Ratio

33.3162

.7613

(1.44)

(24.72)

Labor Force Participation Rate

29.6164

.7590

(0.97)

(24.58)

Unemployment Rate

$-59.6858$

.7613

(1.94)

(24.78)

Note: See note on table 3. The dependent variables in the top panel of the table are macroeconomic outcomes $(Y)$. Weeks of parental leave $(L)$ are the regressands in the bottom panel. 
Table 5: Fixed-Effect Estimates of the Relationship Between Unpaid and

Paid Parental Leave and Macroeconomic Outcomes

\begin{tabular}{|c|c|c|c|c|}
\hline Regressor & $\begin{array}{c}\text { Log of Gross } \\
\text { Domestic } \\
\text { Product }\end{array}$ & $\begin{array}{c}\text { Employment- } \\
\text { to-Population } \\
\text { Ratio }\end{array}$ & $\begin{array}{c}\text { Labor Force } \\
\text { Participation } \\
\text { Rate }\end{array}$ & $\begin{array}{c}\text { Unemployment } \\
\text { Rate }\end{array}$ \\
\hline & (1) & (2) & (3) & (4) \\
\hline UNPAID & $\begin{array}{c}-.000151 \\
(0.41)\end{array}$ & $\begin{array}{c}.002254 \\
(2.24)\end{array}$ & $\begin{array}{c}.002420 \\
(2.94)\end{array}$ & $\begin{array}{c}.006182 \\
(2.01)\end{array}$ \\
\hline UNPAID SQUARED & $\begin{array}{c}8.76 E-7 \\
(0.27)\end{array}$ & $\begin{array}{c}-2.77 E-5 \\
(3.06)\end{array}$ & $\begin{array}{c}-2.63 E-5 \\
(3.57)\end{array}$ & $\begin{array}{c}-2.59 E-5 \\
(0.86)\end{array}$ \\
\hline P-Value & .8462 & .0006 & .0005 & .0001 \\
\hline \multicolumn{5}{|l|}{ "Maximum" Unpaid } \\
\hline PAID & $\begin{array}{l}.002386 \\
(3.23)\end{array}$ & $\begin{array}{c}.003436 \\
(1.43)\end{array}$ & $\begin{array}{c}.000808 \\
(0.41)\end{array}$ & $\begin{array}{c}-.011896 \\
(1.77)\end{array}$ \\
\hline PAID SQUARED & $\begin{array}{c}-1.80 \mathrm{E}-5 \\
(1.85)\end{array}$ & $\begin{array}{c}-5.37 E-6 \\
(0.17)\end{array}$ & $\begin{array}{c}2.32 E-6 \\
(0.09)\end{array}$ & $\begin{array}{c}8.92 \mathrm{E}-5 \\
(1.05)\end{array}$ \\
\hline P-Value & .0006 & .0035 & .4246 & .0484 \\
\hline \multicolumn{5}{|l|}{ "Maximum" } \\
\hline $\begin{array}{l}\text { Paid Leave } \\
\text { Effect }\end{array}$ & 66.3 wks & 319.9 wks & no maximum & 66.7 wks \\
\hline
\end{tabular}

Note: See note on table 3. UNPAID and PAID respectively refer to the number of weeks of job-protected maternity leave with and without pay. 
Table 6: Fixed-Effect Estimates of the Relationship Between

Parental Leave and Female Labor Force Outcomes

\begin{tabular}{|c|c|c|c|}
\hline Regressor & $\begin{array}{l}\text { Employment-to- } \\
\text { Population Ratio }\end{array}$ & $\begin{array}{c}\text { Labor Force } \\
\text { Participation Rate }\end{array}$ & $\begin{array}{c}\text { Unemployment } \\
\text { Rate }\end{array}$ \\
\hline LEAVE & $\begin{array}{l}.003836 \\
(2.29)\end{array}$ & $\begin{array}{l}.001669 \\
(0.94)\end{array}$ & $\begin{array}{l}.008561 \\
(1.68)\end{array}$ \\
\hline LEAVE SQUARED & $\begin{array}{l}-3.34 \mathrm{E}-5 \\
(2.45)\end{array}$ & $\begin{array}{l}-1.73 E-5 \\
(1.22)\end{array}$ & $\begin{array}{l}-6.70 \mathrm{E}-5 \\
(1.63)\end{array}$ \\
\hline P-Value & .0406 & .1796 & .2436 \\
\hline "Maximum" Leave Effect & 58.1 wks & 48.2 wks & 63.9 wks \\
\hline UNPAID & $\begin{array}{l}.003330 \\
(2.41)\end{array}$ & $\begin{array}{l}.001959 \\
(1.37)\end{array}$ & $\begin{array}{l}.019295 \\
(4.96)\end{array}$ \\
\hline UNPAID SQUARED & $\begin{array}{c}-3.53 \mathrm{E}-7 \\
(2.51)\end{array}$ & $\begin{array}{l}-2.48 \mathrm{E}-5 \\
(1.68)\end{array}$ & $\begin{array}{l}-.000195 \\
(4.79)\end{array}$ \\
\hline P-Value & .0437 & .1477 & .0000 \\
\hline "Maximum" Unpaid Leave Effect & 46.7 wks & 39.5 wks & 49.4 wks \\
\hline PAID & $\begin{array}{c}-1.82 \mathrm{E}-5 \\
(0.01)\end{array}$ & $\begin{array}{l}.000683 \\
(0.24)\end{array}$ & $\begin{array}{c}-.002508 \\
(0.34)\end{array}$ \\
\hline PAID SQUARED & $\begin{array}{l}1.84 E-5 \\
(0.55)\end{array}$ & $\begin{array}{l}-2.13 \mathrm{E}-5 \\
(0.60)\end{array}$ & $\begin{array}{l}-1.38 \mathrm{E}-5 \\
(0.15)\end{array}$ \\
\hline P-Value & .0035 & .5833 & .3632 \\
\hline "Maximum" Paid Leave Effect & no maximum & 16.0 wks & 90.9 wks \\
\hline Sample Size & 330 & 325 & 323 \\
\hline
\end{tabular}

Note: See notes on tables 3 and 5. 
Table 7: Predicted Values of Outcome Variables at Different

Durations of Unpaid and Paid Parental Leave

\begin{tabular}{|c|c|c|c|c|c|c|}
\hline $\begin{array}{l}\text { Duration } \\
\text { and Type } \\
\text { of Leave }\end{array}$ & $\begin{array}{l}\text { Log of } \\
\text { Per } \\
\text { Capita } \\
\text { GDP }\end{array}$ & EMP/POP & LFPR & $\begin{array}{c}\text { UNEMP } \\
\text { Rate }\end{array}$ & $\begin{array}{c}\text { Female } \\
\text { EMP/POP }\end{array}$ & $\begin{array}{c}\text { Female } \\
\text { LFPR }\end{array}$ \\
\hline
\end{tabular}

$\begin{array}{llllllll}\text { No Leave } & 9.069 & 58.7 \% & 63.9 \% & 6.8 \% & 43.0 \% & 47.3 \% & 5.8 \%\end{array}$

Unpaid Leave

$\begin{array}{llllllll}10 \text { weeks } & 9.067 & 59.2 & 64.4 & 7.2 & 43.8 & 47.8 & 6.9 \\ 25 \text { weeks } & 9.066 & 59.6 & 65.0 & 7.7 & 44.5 & 48.2 & 8.2 \\ 50 \text { weeks } & 9.063 & 59.8 & 65.2 & 8.5 & 44.9 & 48.2 & 9.1 \\ 75 \text { weeks } & 9.062 & 59.0 & 64.7 & 9.1 & 44.2 & 47.5 & 8.1\end{array}$

Paid Leave

$\begin{array}{llllllll}10 \text { weeks } & 9.091 & 59.5 & 64.1 & 6.1 & 43.1 & 47.5 & 5.7 \\ 25 \text { weeks } & 9.117 & 60.7 & 64.4 & 5.4 & 43.3 & 47.4 & 5.5 \\ 50 \text { weeks } & 9.143 & 62.5 & 65.0 & 4.8 & 44.1 & 46.9 & 5.0 \\ 75 \text { weeks } & 9.146 & 64.1 & 65.6 & 4.7 & 45.5 & 45.6 & 4.5\end{array}$

Note: Table shows predicted values of outcome variables at various durations of unpaid and paid leave. Estimates are based upon the WLS and grouped data Logit models summarized in tables 3,5 , and 6 , with variables other than maternity leave evaluated at their sample means. 
Fig 1: Average Weeks of Family Leave (Unweighted)

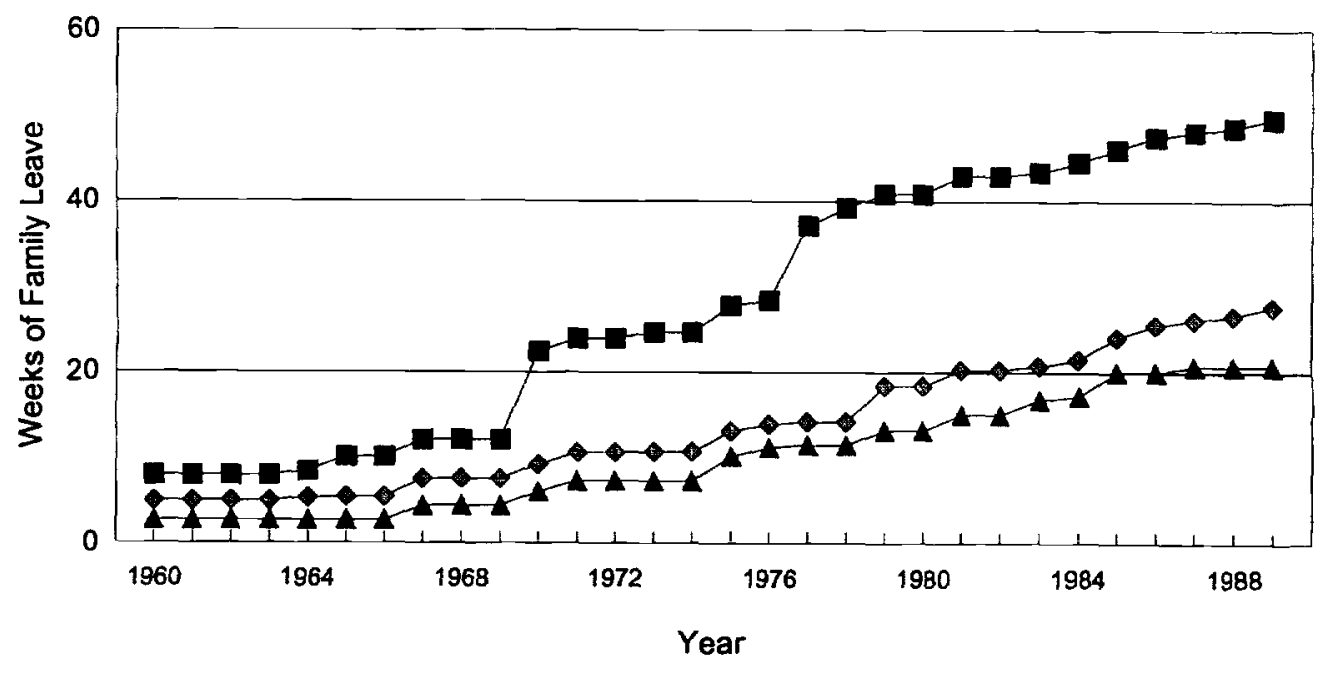

Total Leave $\quad$ Paid Leave \& Full Pay Weeks

Fig 2: Average Weeks of Family Leave (Weighted)

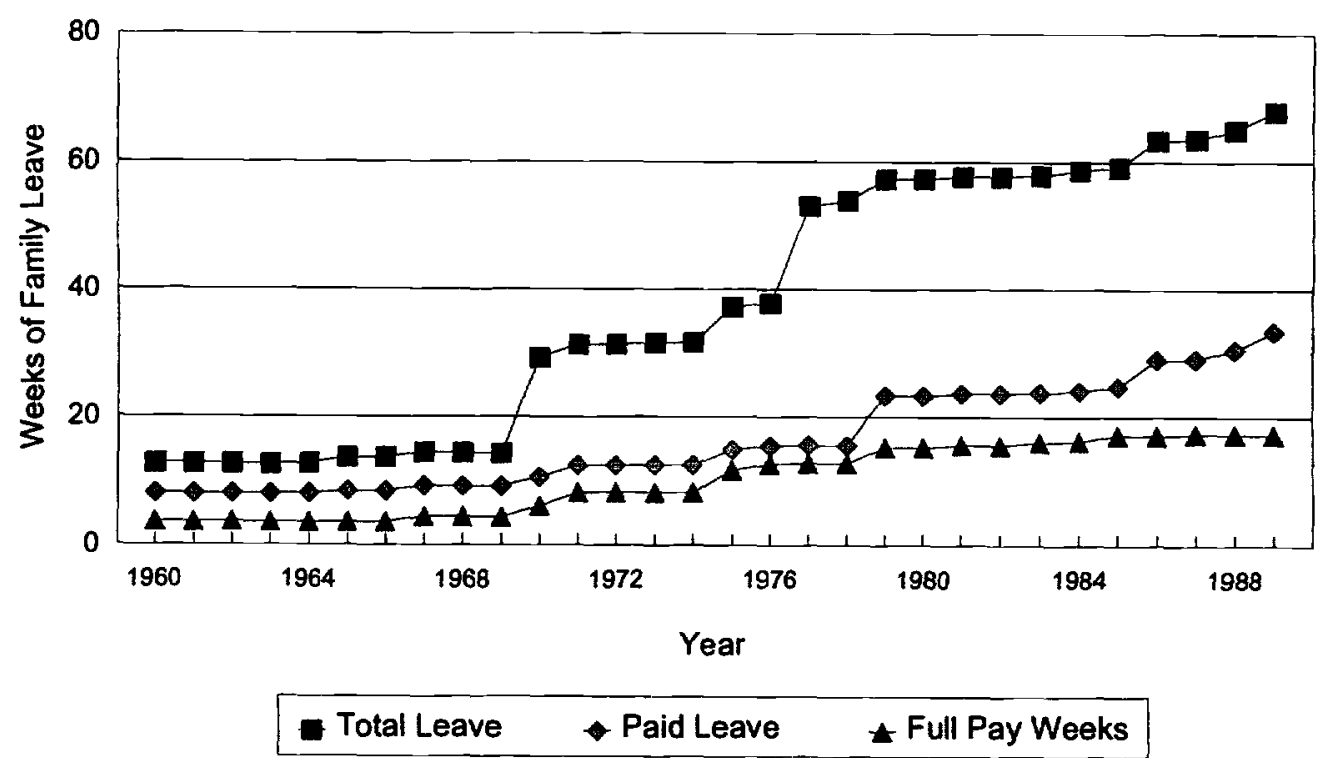


Figure 3: Relationship Between Family Leave, GDP, and Working Age Population
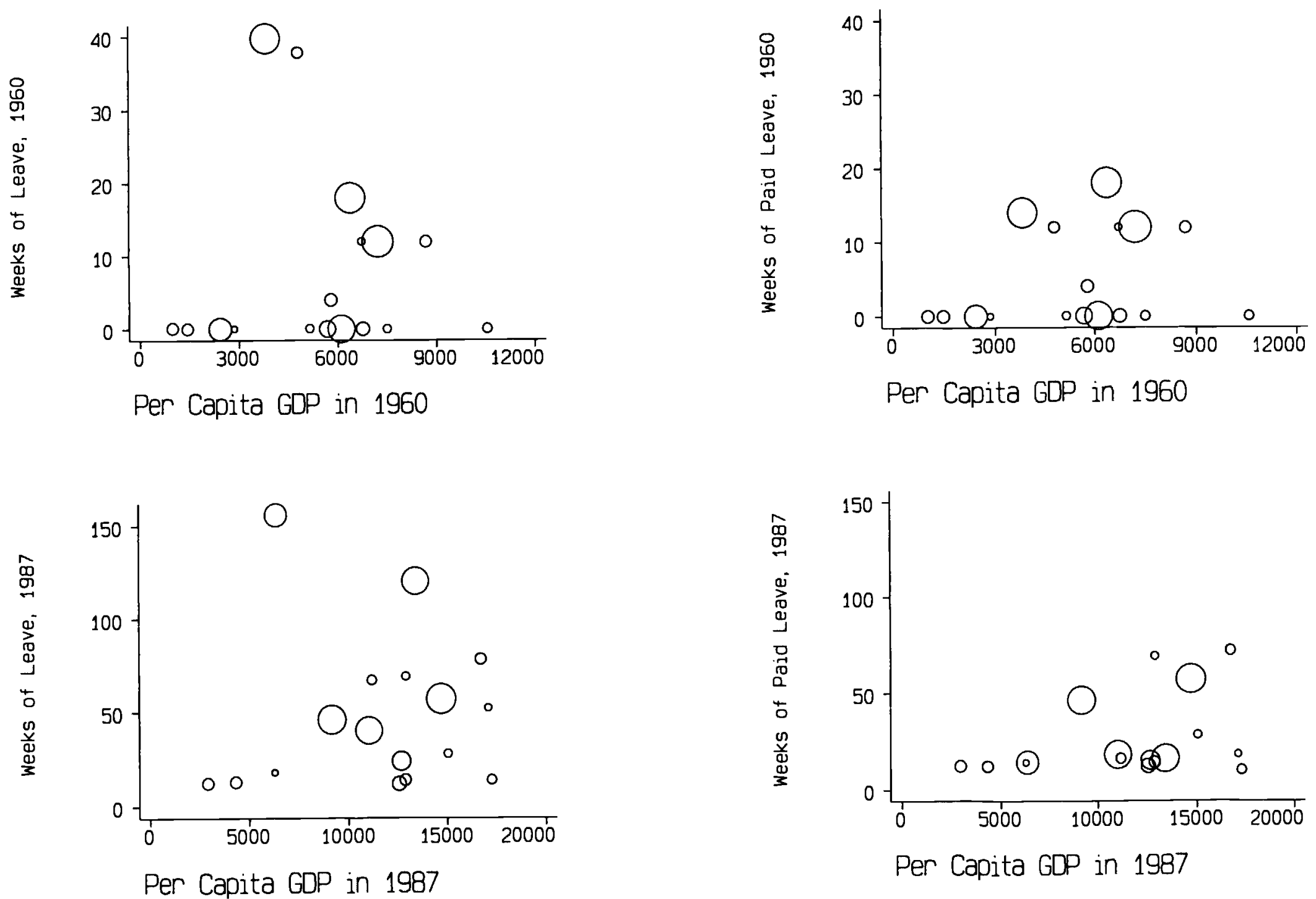

Per Capita GDP in 1987 